\title{
ADAPTATION AND TESTING OF AN INSTRUMENT TO MEASURE ENERGY LITERACY IN MEXICO
}

\author{
G. Castañeda-Garza and G. Valerio-Ureña \\ Tecnológico De Monterrey, Mexico
}

\begin{abstract}
We live in a continuous dependence to energy, and yet, there does not exist a clear sight about what we know and what we ignore about energy. Energy literacy is a broad term encompassing content knowledge as well as a citizenship understanding of energy that includes affective and behavioral aspects. In this study, of quantitative nature with exploratory scope, the purpose was to create an adaptation, and application of a pilot test, of the questionnaire "Energy Literacy Survey" (DeWaters \& Powers, 2009) in a sample of university students from Mexico. The method included a translation procedure, the regional adaptation and the development of the pilot test. The sample consisted in a total of 114 participants. The questionnaire was made of 64 items in three sub-scales (cognitive, affective and behavioral). Being an adaptation from an original instrument, reliability and relevance of the items were evaluated. Factorial analysis was used to evaluate the importance of the items. Affective sub-scale showed values superior to 0.5 , suggesting relevance in those items, except for two items (A7 and A8). Behavior sub-scale reports as well most of its values superior to 0.5, with exception of items B4 and B10. In terms of reliability, Cronbach's alpha was calculated. The affective sub-scale obtained 0.581 , being able to increase its value to 0.652 if A5 was removed. On the other hand, behavior sub-scale obtained 0.691 , being able to increase to 0.710 if one item was removed. Results of the pilot show differences between students of the faculties of science, engineering and others, as well as differences by gender. Lastly, applications for the instrument are discussed as well as some opportunities to improve it.
\end{abstract}

Keywords: Education, society and environment, sustainable development, energy, measurement scales

\section{Introduction}

Even when most of the blackouts and electric transmission problems last only a few hours, some last days, or even, weeks. The reach that these may have can affect domestic and industrial users, crossing through critical infrastructure as telecommunications networks, the financial sector, sewer systems and hospitals (Hodge, 2015). Climate change is an issue that needs to be addressed (Trischler, 2017); according to different authors, its impact will promote an increase in the demand of energy in the following years (Sharifi \& Yamagata, 2015; Skamp, Boyes, \& Stanisstreet, 2013). Human settlements are under the effect of a variety of risks and dangers by natural hazards; moreover, it is expected the climate change will change the intensity and frequency of these dangers (Sharifi \& Yamagata, 2015).

Some authors point that there exist a need to consider the risk of a potential failure to the energy distribution system if there taken in account that the existent transmission lines were designed for the needs of past decades, and can be not prepared for the actual demand or the entry of 'volatile renewable energy' (Hodge, 2015). A power outage, without considering its specific cause, has a relevant impact in the economy. As an example, in August 14, 2003, great part of the mid-west and north-east territory of United States and Ontario, Canada suffered a blackout that lasted to four days in some regions. The calculated damage by the event ascended close to US \$6 billion dollars (Hodge, 2015). In August 15, 2017. Taiwan suffered a power outage. Even if it only 
lasted around five hours, the economic impact was calculated close to US \$2.9 million dollars (Reuters, 2017). Another similar case occurred in Mexico. In September 10, 2017, a technical fault interrupted the operation of an energy substation, interrupting the supply of energy: nearly 3.23 million of customers were affected and more than 4 hours were required to reestablish the service (CFE, 2017). The president of the Camera of the Transformation Industry (CAINTRA) pointed that the power outage caused millionaire losses to the $99 \%$ of the industry of Nuevo Leon (Valle, 2017). Damage related to the lack of public infrastructure (as hospital equipment or traffic lights) are not usually contemplated in the impact of these events, ignoring the impact that it could have in medical procedures and care, as well as the possible accidents promoted by the lack of electricity in the infrastructure that requires it (i.e. traffic lights).

In the Estrategia Nacional de Energía 2014 - 2028 (National Energy Strategy) established by the Secretary of Energy of Mexico, it is declared the need to concrete energy security, which is defined as: "The capacity to maintain an energy surplus that brings certainty to continue with the development of productive activities, in addition to increase the accessibility to the markets, integration of products and preventive storage, mainly focused in those energy resources whose dependence by imports could increase to levels associated to the continuity of supply (SENER, 2014; p. 35). An opportunity in this plan is the measurement of the population understanding about energy. Today, there does exist measurements about the consumption of electricity in the international and national spheres. Globally, around one fifth of the demand of global energy ( 20\%) is used by the residential sector (Brounen, Kok, \& Quigley, 2013). In Mexico, this sector is around 18.7\% (Valdez, Mayo, \& Ortiz, 2016). However, relationships between the beliefs, knowledges and attitudes of the population towards topics related to energy are not being measured, and this could be relevant to understand better which interactions exist between, for example, the knowledge of the national policy for energy development and the beliefs, or in which grade there exist a relationship between a set of attitudes and beliefs.

\section{Theoretical Framework}

Energy literacy is a broad term encompassing content knowledge as well as a citizenship understanding of energy that includes affective and behavioral aspects (DeWaters \& Powers, 2013). DeWaters and Powers (2013) affirm that a "successful shift into a stable future will rely not only on qualified technical, scientific, and professional expertise, but also on the ability of the average citizen to make appropriate energy-related choices that range from mode of transportation to consumer purchases and voting habits" (p. 38). According to outlooks of the future, we are going towards a world in which the global population is increasing from 7.3 billion people to 9.2 billion in 2040 (World Nuclear Association, 2017). This will exert a major stress on the environment, through the resources needed for the cities and in the health of people. On the other hand, to remedy the impact of a greater population, generate energy using non-fossil sources will be needed, taking in account that only in 2012 these were related to an approximate of 7 million deaths due to air pollution (OMS, 2014). To ensure wellbeing, prosperity and the security of the cities, some authors consider that there are three factors that should be studied for their adequate care and preservation: water, food and energy (Schlör, Venghaus, \& Hake, 2016). With the purpose of finding ways to assess the understanding of students in topics related to energy, there have been efforts to develop instruments to measure their knowledge associated to climate change and energy use. For that, the construct 'energy literacy' stands out. In Spanish, the term 'energy literacy' has been adapted to 'alfabetización energética'.

The relevance of energy literacy has been discussed by many authors, some of them considering it as a 'skill for life' that allows to understand, brings knowledge and empowers students and the public (...) to take better decisions around energy and the electric supply (DeWaters, Qaqish, Graham \& Powers, 2013; DeWaters \& Powers, 2011; Lee, Lee, Altschuld \& Pan, 2015). Considered, it is understood that an instrument to measure the levels of energy literacy should consider the concerns in politics, socioeconomic and environmental, that affect a determined society, by which some authors have developed their own adaptations of the instrument to their particular context (Cotton, Miller, Winter, Bailey, \& Sterling, 2015; Lee, Lee, Altschuld \& Pan, 2015). For the 
purposes of this research, the work developed by DeWaters, Qaqish, Graham \& Powers (2013) has been taken into account, since the relevance that the authors have had for other studies (DeWaters \& Powers, 2011; Cotton, Miller, Winter, Bailey \& Sterlin, 2015). In Table 1, an example of the different components of energy literacy is presented.

Table I. Example of the sub-scales used by DeWaters et al., 2013 for the measurement of energy literacy

\begin{tabular}{lll}
\hline $\begin{array}{l}\text { Attribute } \\
\text { (definition) }\end{array}$ & $\begin{array}{l}\text { Example characteristics } \\
\text { (descriptive) }\end{array}$ & Example benchmarks (measurable) \\
\hline Cognitive & Know basic energy concepts & $\begin{array}{l}\text { Identify forms of energy } \\
\text { Apply first and second laws of energy. }\end{array}$ \\
\hline Affective & $\begin{array}{l}\text { Positive energy related- } \\
\text { attitudes. }\end{array}$ & $\begin{array}{l}\text { Reduce environmental impacts related to energy use. } \\
\text { Economic responsibility for using renewable resources. }\end{array}$ \\
\hline Behavioral & Energy-saving habits & Energy consumption patterns. \\
\hline
\end{tabular}

Being that the instrument of DeWaters et al. was applied in a cultural context different to one in Mexico, and the concept has not been found to be studied in the literature in Spanish, the purpose of this work is to present our first adaptation to the Mexican context of the instrument made by the original authors and to present the results of the first run made with such adaptation. This exploratory study evaluates the levels of energy literacy in students of a private university in Mexico.

\section{Method}

\section{Instrument and adaptation}

A quantitative study with exploratory scope was made, using an adaptation of the Energy Literacy Survey (DeWaters, 2009), translated from English to Spanish. This questionnaire consists in a test originally made to be taken with paper and pencil, focused on students of high school level. The original instrument includes a total of 69 items, divided in four sections:

- Section I (4 questions) Explores (using multiple option questions) about the beliefs of knowledge, auto concept of energy use, sources of learning about energy and familiar communication towards energy.

- Section II (17 questions) Affective sub-scale. Uses a Likert scale from 1-5, being 1 "totally disagree" and 5 "totally agree".

- Section III (10 questions) Behavior sub-scale. Uses a Likert scale from 1-5, being 1 "totally disagree" and 5 "totally agree".

- $\quad$ Section IV (38 questions) Cognitive sub-scale. Includes questions with multiple option answers and is scored with " 1 " if the answer is correct, or " 0 " if not.

Some items were adapted to provide a more suitable instrument for the context. Examples of this were questions related to the country situation (i.e. Which is the fossil fuel more abundant in US? to Which is the fossil fuel more abundant in Mexico?) or corrected, because of a wrong meaning (i.e. item 19 specifies Europe as a country). Most of the items were written with no specialized language. Translation was made by the main author of this work. Validation of the items was done through five cognitive interviews, in which the comprehension of participants was explored. Five people were invited to voluntary participate. Three of them were from engineering field, two from social sciences fields. Comments made by the participants showed that there does exist doubts towards the adaptation of some questions that, originally, treated topics related to the US context, physics of fission and fusion, and others. Data from the doubts of the participants was gathered, consequently, 
changes were made in the questionnaire to make it more understandable for a Mexican sample. Since no experts were found available during this study to clarify these questions, items 38, 49, 59, 68 and 69 were removed, since no correct answer known to those questions.

\section{Sample}

As demographic variables, gender, bachelor degree and school/faculty were considered with the objective of being able to compare the possible existing differences between faculties and gender with the different items of the questionnaire. The sample consisted only in undergraduate students in a private university in the city of Monterrey, Nuevo Leon, Mexico. Other selection criteria were to promote a balance between the gender of the participants, aiming to get a percentage of participation close to $50 \%$ by each one, as well with the students from the School of Engineering and Science and the other schools. The purpose of doing this was to have a control group to test if students from the School of Engineering and Science scored better, and to understand more about the differences by gender and faculty.

\section{Data Collection}

To collect data, Google Forms was used and it occurred during the second half of November 2017. Collection of data oversaw three people: two interviewers (author and an interviewer) and one sub-director of an engineering bachelor. Around $50 \%$ of the participants answered the questionnaire in front of the interviewer, while another half participated through closed virtual groups related to engineering careers. Instructions about the educative and research purpose of the instrument and a general description were presented in the beginning: the number of sections, questions and approximate time required to answer. Also, it is made clear that the questionnaire is not an exam, so no score will be received, but that answers will allow to understand better about energy. Finally, it is stated that participation is voluntary, allowing the participant to stop answering in the moment that the participant wishes, and that the data will be used confidentially.

\section{Data analysis}

Entries from 116 participants were obtained, from which two were discarded: one because being mostly in blank, another entry because it was a duplicate. In total, 114 entries were analyzed. Resulting sample consisted in 63 men (59\%) and 51 women (41\%). Participation by faculty consisted in 13 participants (8.49\%) from the School of Social Sciences and Government, 6 from the School of Humanities and Education (5.35\%), 59 of the School of Engineering and Sciences (56.45\%), 31 from School of Medicine and Health Sciences (5.35\%) and 5 from the School of Business (4.46\%). Being an adaptation from an original instrument, reliability and relevance of the items was evaluated. Factorial analysis is suggested to evaluate the importance of an item in the measurement of a construct. Affective sub-scale showed values superior to 0.5 , suggesting relevance in those items, except for A7 and A8. Behavior sub-scale reports as well most of its values superior to 0.5, with exception of items B4 and B10. In terms of reliability, Cronbach alpha was calculated. The affective sub-scale obtained 0.581, being able to increase to 0.652 if A5 was removed. ON the other hand, behavior sub-scale obtained 0.691 , being able to increase to 0.718 if one item was removed.

\section{Results}

Exploring the first questions related to understand which sources have contributed more to the understanding about energy of the participants, the results are:

Considering gender, it is found that men point that most of their learning of energy topics is thanks to books, magazines and newspapers ( 35 times selected by men, 14 by women). More results are showed in Table II. 
Table II. Sources that contribute to the understanding of energy issues (comparison by faculty and gender)

\begin{tabular}{lllllll}
\hline \multicolumn{7}{l}{ Sources that contribute to the understanding of energy } \\
\hline Faculty & School & Book & Internet & TV & Friends/Family & Newspaper/Magazine \\
\hline Men & & & & & & \\
\hline $\begin{array}{l}\text { School of Engineering } \\
\text { and Science }\end{array}$ & 36 & 24 & 26 & 3 & 13 & \\
\hline Other schools & 13 & 11 & 13 & 0 & 8 & 11 \\
\hline Total men & 49 & 35 & 39 & 3 & 21 & 35 \\
\hline Women & 15 & 6 & 11 & 1 & 3 & 6 \\
\hline $\begin{array}{l}\text { School of Engineering } \\
\text { and Science }\end{array}$ & 16 & 8 & 21 & 7 & 14 & 8 \\
\hline Other schools & 16 & 14 & 32 & 8 & 17 & 49 \\
\hline Total women & 31 & 49 & 71 & 11 & 38 \\
\hline Total & 80 & & & & & \\
\hline
\end{tabular}

Note: Between the differences, is important to mark the closeness in the number of times that school and internet are pointed as sources of the understanding of energy.

In Table III data associated to the differences found between the score of both genders in the questionnaire and their sub-scales (affective, behavior and cognitive) is presented. A significative difference of four points between the mean obtained in the cognitive sub-scale (C) by men (22.06) compared to women (19.94) was found). Comparing men of the School of Engineering and Science to other the control group (other schools) not significant differences were found in the affective and behavior sub-scales, except in the cognitive sub-scale where there exist a difference of three points (23.02) over the control group (20.14). In contrast, women from the School of Engineering and Sciences obtained a mean of 21.35 compared to 17.74 from the other women in the control group in the cognitive sub-scale, as well as having a slightly higher mean (40.24) in the behavior sub-scale.

Table III. Differences between mean $(m)$ of the points obtained by both genders when compared by school

\begin{tabular}{llllll}
\hline Faculty & Participants & $\mathrm{m}(\mathrm{A})$ & $\mathrm{m}(\mathrm{B})$ & $\mathrm{m}(\mathrm{C})$ & $\mathrm{m}$ (Total) \\
\hline Men & & & & & \\
\hline $\begin{array}{l}\text { School of Engineering } \\
\text { and Science }\end{array}$ & 42 & 61.38 & 40.14 & $23.02^{*}$ & $124.55^{*}$ \\
\hline $\begin{array}{llll}\text { Other schools } \\
\text { Total men }\end{array}$ & 21 & 60.43 & 40.48 & 20.14 & 121.05 \\
\hline Women & 63 & 61.06 & 40.25 & 22.06 & 123.38 \\
\hline $\begin{array}{l}\text { School of Engineering } \\
\text { and Science }\end{array}$ & 17 & & & & \\
\hline Other schools & 34 & 60.59 & $40.24 *$ & $21.35^{*}$ & $122.18^{*}$ \\
\hline Total women & 51 & 60.47 & 38.09 & 17.74 & 116.29 \\
\hline Total & 114 & 60.51 & 38.80 & 18.94 & 118.25 \\
\hline
\end{tabular}


Responses of the participants were studied in the cognitive sub-scale, identifying items and their respective difficulty levels. Listed items in the Table IV show the difficulty level (through difficulty index) of some that were frequently answered wrong. Difficulty index is a measure by which is calculated the difficulty of every item, as a proportion of the right answers in each one (Pérez, 2017).

Table IV. Difficulty index of the cognitive sub-scale, compared by faculty and gender

\begin{tabular}{|c|c|c|c|c|c|c|c|c|}
\hline \multirow[b]{2}{*}{ Item } & \multirow[b]{2}{*}{$\begin{array}{l}\text { Difficulty } \\
\text { index }\end{array}$} & \multicolumn{3}{|c|}{ School of Engineering and Science } & \multicolumn{4}{|c|}{ Other Schools } \\
\hline & & Men & Women & Both & Men & Women & Both & $\begin{array}{l}\text { Sample in } \\
\text { general }\end{array}$ \\
\hline $\mathrm{C} 3$ & 0.429 & & & & $\mathrm{x}$ & $\mathrm{x}$ & $\mathrm{x}$ & $\mathrm{x}$ \\
\hline C6 & 0.561 & & & & & $\mathrm{x}$ & & \\
\hline $\mathrm{C} 14$ & 0.184 & $\mathrm{x}$ & $\mathrm{x}$ & $\mathrm{x}$ & $\mathrm{x}$ & $\mathrm{x}$ & $\mathrm{x}$ & $\mathrm{x}$ \\
\hline $\mathrm{C} 20$ & 0.236 & $\mathrm{x}$ & $\mathrm{x}$ & $\mathrm{x}$ & $\mathrm{x}$ & $\mathrm{x}$ & $\mathrm{x}$ & $\mathrm{x}$ \\
\hline $\mathrm{C} 25$ & 0.080 & $\mathrm{x}$ & $\mathrm{x}$ & $\mathrm{x}$ & $\mathrm{x}$ & $\mathrm{x}$ & $\mathrm{x}$ & $\mathrm{x}$ \\
\hline $\mathrm{C} 26$ & 0.333 & & $\mathrm{x}$ & & & $\mathrm{x}$ & $\mathrm{x}$ & $\mathrm{x}$ \\
\hline C32 & 0.377 & & $\mathrm{x}$ & & & $\mathrm{x}$ & $\mathrm{x}$ & $\mathrm{x}$ \\
\hline C34 & 0.342 & & & & $\mathrm{x}$ & $\mathrm{x}$ & $\mathrm{x}$ & $\mathrm{x}$ \\
\hline
\end{tabular}

\section{Conclusion}

In this study, we have explored the first results of an adaptation of an instrument to measure energy literacy. Issues open to discussion during the development of this work show potential opportunities to improve for the future. Some aspects of external and internal validity were identified. For example, making a more detailed work focused on standardize of the Spanish language in the questionnaire and limited to only a region of Mexico. Other important issue was the date of the study, being that this research was made during exams season, which could affect the answers of the participants. Concerning internal validity, we consider important to remember that not all the original items were included in this test due to some items required specialized knowledge of energy or socioeconomic issues in Mexico. Therefore, a review from professionals related to the energy field would provide confirmation of these specialized items. Other issue to observe is that the Energy Literacy Survey was originally designed for middle school and high school students in USA, in a paper and pencil format, while this work focused on a sample of university students in Mexico, using Google Forms as the platform to gather the answers. Despite of this, results show that cognitive (knowledge) about energy issues from a variety of perspectives seems to be 'average' in general, having a mean of 20.67 of 33 in the cognitive sub-scale, representing a $62 \%$ of correct answers.

Gender differences were observed as well, finding that males normally have superior scores compared to women, however, females in engineering or science careers seem to point better than men in other fields in the same sub-scale. As well, is to be appreciated that participants affirm that school and internet were the most frequent sources of learning about energy. Regarding to the reliability of the instrument, DeWaters and Powers (2011) report a Cronbach alpha in their three sub-scales in a range of 0.70 to 0.82 . This is far from ideal in this research that reports in a range from 0.581 to 0.691 . However, if some items from the affective and behavioral sub-scales were to be removed, the range could increase to 0.652 to 0.718 . On the other hand, being that correct procedure to evaluate the validity of the cognitive sub-scale is unknown to the main author, information regarding the reliability is not presented.

The future is yet, unseen; however, increasing energy needs are expected. Today, predictions allow us to capture a sight of how the world will be someday in the tomorrow, in a world and a generation (millennial and the 
coming $\mathrm{Z}$ generation) that, different to their predecessors, has lived rapid changes in technology but has not experienced or being used to the lack of internet, refrigeration, communications, a life around energy.

If the future becomes more and more immerse into the digital and electronic, and continues towards a tendency of integration of technology into our lives, it's important to be prepared to face scenarios were it will be needed to provide a certain standard of life that, until now, just belongs to a small sector of the global population - or in other scenario, understand better how to react in cases where the energy infrastructure is unable to supply our cities, or emergency situations difficult its production or transmission. As it was implied in the beginning of this research: We are increasingly dependent on energy, even if we are not aware of it.

\section{Acknowledgement}

The authors would like to acknowledge the financial support of Writing Lab, TecLabs, Tecnologico de Monterrey, Mexico, in the production of this work.

\section{References}

Brounen, D., Kok, N., \& Quigley, J. M. (2013). Energy literacy, awareness, and conservation behavior of residential households. Energy Economics, 38, 42-50. https://doi.org/10.1016/j.eneco.2013.02.008

CFE. Afecta falla en subestación suministro de energía eléctrica en algunas ciudades de los Estados de Nuevo León, Coahuila, Tamaulipas y Chihuahua, Pub. L. No. 8460, Comisión Federal de Electricidad (2017). México. Retrieved from http://saladeprensa.cfe.gob.mx/boletines/show/8460/

Cotton, D. R. E., Miller, W., Winter, J., Bailey, I., \& Sterling, S. (2015). Developing students' energy literacy in higher education. International Journal of Sustainability in Higher Education, 16(4), 456-473. https://doi.org/10.1108/IJSHE-12-2013-0166

DeWaters, J. (2009). Energy Literacy Survey. High School Issue. Potsdam, EUA. Retrieved from http://www.esf.edu/outreach/k12/solar/2011/documents/energy_survey_HS_v3.pdf

DeWaters, J. E., \& Powers, S. E. (2011). Energy literacy of secondary students in New York State (USA): A measure of knowledge, affect, and behavior. Energy Policy, 39(3), 1699-1710. https://doi.org/10.1016/j.enpol.2010.12.049

DeWaters, J., \& Powers, S. (2013). Establishing measurement criteria for an energy literacy questionnaire. Journal of Environmental Education, 44(1), 38-55. https://doi.org/10.1080/00958964.2012.711378

DeWaters, J., Qaqish, B., Graham, M., \& Powers, S. (2013). Designing an energy literacy questionnaire for middle and high school youth. Journal of Environmental Education, 44(1), 56-78. https://doi.org/10.1080/00958964.2012.682615

Hodge, N. (2015). Energy Risks - the dangers of power cuts and blackouts. Retrieved from http://www.agcs.allianz.com/insights/expert-risk-articles/energy-risks/

Lee, L. S. (2011). Identifying energy literacy for the upper-secondary students in Taiwan. Recent Researches in Energy, Environment, Entrepreneurship, Innovation - International Conference on Energy, Environment, Entrepreneurship, Innovation, ICEEEI'11, 134-137.

Lee, L. S., Lee, Y. F., Altschuld, J. W., \& Pan, Y. J. (2015). Energy literacy: Evaluating knowledge, affect, and behavior of students in Taiwan. Energy Policy, 76, 98-106. https://doi.org/10.1016/j.enpol.2014.11.012

Organización Mundial de la Salud (OMS) (2014). 7 million premature deaths annually linked to air pollution. Retrieved October 4, 2017, from http://www.who.int/mediacentre/news/releases/2014/air-pollution/en/

Pérez, R. O. (2017). Test conceptual de Física cuántica para estudiantes de ingeniería. Revista Electrónica de Investigación Educativa, 19(4), 35-49.

Reuters. (2017, August 17). Taiwan power outage affected 151 companies, caused $\$ 3$ million in damages. Reuters. Retrieved from http://www.reuters.com/article/us-taiwan-power-outages/taiwan-power-outageaffected-151-companies-caused-3-million-in-damages-idUSKCN1AX0S3?il=0

Schlör, H., Venghaus, S., \& Hake, J. F. (2016). The FEW-Nexus city index - Measuring urban resilience. Applied Energy. https://doi.org/10.1016/j.apenergy.2017.02.026 
SENER. (2014). Estrategia Nacional de Energía 2014 - 2028. México. Retrieved from https://www.gob.mx/cms/uploads/attachment/file/214/ENE.pdf

Sharifi, A., \& Yamagata, Y. (2015). A Conceptual Framework for Assessment of Urban Energy Resilience. Energy Procedia, 75, 2904-2909. https://doi.org/10.1016/j.egypro.2015.07.586

Skamp, K., Boyes, E., \& Stanisstreet, M. (2013). Beliefs and Willingness to Act About Global Warming: Where to Focus Science Pedagogy? Science Education, 97(2), 191-217. https://doi.org/10.1002/sce.21050

Trischler, H. (2017). El Antropoceno ¿un concepto geológico, cultural o ambos ? Desacatos, (54), 40-57.

Valdez, J. E., Mayo, J. C., \& Ortiz, E. (2016). Uso de energía en el sector residencial. Retrieved October 4, 2017, from https://youtu.be/ryaxdZZI_TY

Valle, L. (2017, September 12). Pierde por apagón 99\% de la industria. El Norte. Retrieved from http://www.elnorte.com/aplicacioneslibre/preacceso/articulo/default.aspx ?id=1208058\&v=3\&impresion=1\&urlr edirect=http://www.elnorte.com/aplicaciones/articulo/default.aspx ?id=1208058\&v=3\&impresion=1

World Nuclear Association. (2017). World Energy Needs and Nuclear Power. Retrieved October 4, 2017, from http://www.world-nuclear.org/information-library/current-and-future-generation/world-energy-needs-andnuclear-power.aspx 